\title{
DEMONSTRATING DIAMOND WIRE CUTTING OF THE TFTR By:
}
Keith Rule ${ }^{1}$, Erik Perry ${ }^{1}$, S. Larson ${ }^{1}$, M. Viola ${ }^{1}$, Susan Madaris ${ }^{2}$, Robert Rose ${ }^{2}$, Nicholas Jenkins $^{3}$

${ }^{1}$ Princeton Plasma Physics Laboratory, P.O. Box 451, Princeton, New Jersey, 08543 USA,

${ }^{2}$ Florida International University - Hemispheric Center for Environmental Technology, 10555 W. Flagler St., Miami, Fl 33174, ${ }^{3}$ Bluegrass Concrete Cutting, Inc., 107 Mildred St., Greenville, AL 36037

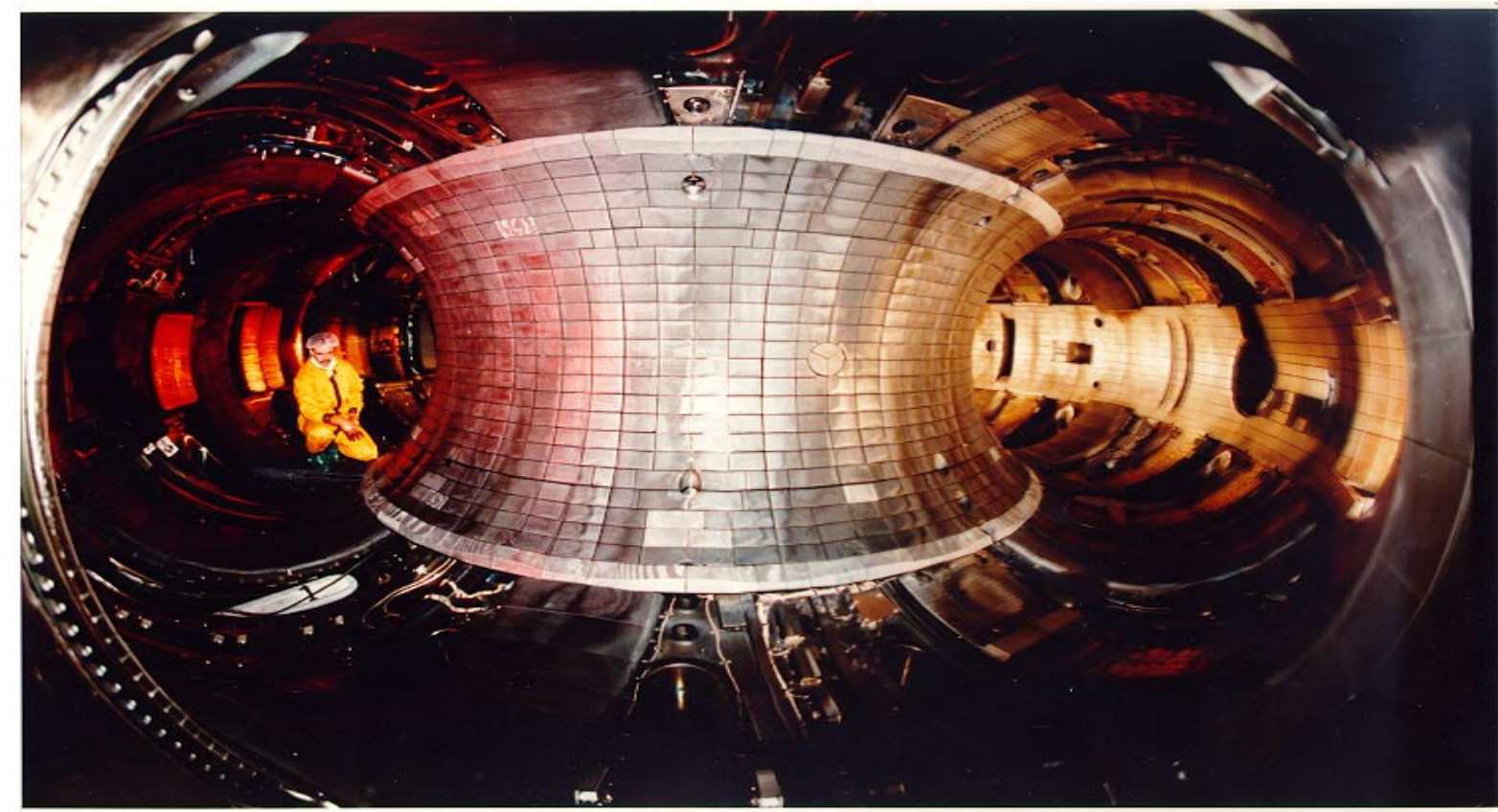

Figure 1 - Internal TFTR vessel (prior to tritium operations)

\begin{abstract}
:
The Tokamak Fusion Test Reactor (TFTR) ceased operation in April 1997 and decommissioning commenced in October 1999. The deuterium-tritium fusion experiments resulted in contaminating the vacuum vessel with tritium and activating the materials with $14 \mathrm{Mev}$ neutrons. The total tritium content within the vessel is in excess of 7,000 Curies while dose rates approach $50 \mathrm{mRem} / \mathrm{hr}$. These radiological hazards along with the size of the Tokamak (100 cubic meters) present a unique and challenging task for dismantling. Plasma arc cutting is the current baseline technology for the dismantlement of fission reactors. This technology is typically used because of its faster cutting times. Alternatively, an innovative approach for dismantlement of the TFTR is the use of diamond wire cutting technology. Recent improvements in diamond wire technology have allowed the cutting of
\end{abstract}


carbon steel components such as pipe, plate, and tube bundles in heat exchangers. Some expected benefits of this technology include: significantly reduction in airborne contaminates, reduced personnel exposure, a reduced risk of spread of tritium contamination, and reduced overall costs as compared to using plasma arc cutting. This paper will provide detailed results of the diamond wire cutting demonstration that was completed in September of 1999, on a mock-up of this complex reactor. The results will identify cost, safety, industrial and engineering parameters, and the related performance of each situation.

\section{BACKGROUND:}

The baseline planning for dismantling the vacuum vessel utilizes plasma arc torch cutting. This involves personnel entry into the vessel using air supplied bubble suits to access and remove internal components. Some components can be removed by mechanical needs while others require plasma cutting. The use of the plasma torch would require additional specialized equipment, which requires dedicated engineering and specialized fabrication remote/semi-remote cutting operations. The plasma arc torch would also result in the release of radioactive airborne contamination and harmful gases requiring extensive containment, filtering, and respiratory protection.

Diamond wire cutting was developed in the early 1980's and has been successfully applied to the cutting of reinforced concrete. This technology has been successfully used on a variety of commercial and government facility decontamination and decommissioning (D\&D) projects such as Trojan and 105c reactors at Hanford for the removal of large mass concrete. Concerns for expanded application of this technology is kerf closure, metal plating of diamond wire, and hazards associated with water-cooling. These concerns were addressed by testing various void fillers that are expected to maintain the structural integrity of the vessel during cutting, clean the diamond bits as they cut through the vessel, limit the dispersal of contaminants, and provide shielding during cutting operations.

The purpose of this demonstration was to perform a complete cut of a multi-layer reactor vessel surrogate (TFTR) with multiple steel content (Inconel, stainless steel alloys) by integrating the use of various void fillers with the DWC system

\section{CONSTRUCTION:}

A test bed was designed and constructed to accommodate multiple cutting scenarios. The vacuum vessel surrogates (four constructed) were of the same geometric shape as the TFTR vacuum vessel and fabricated from 1/2" 304 stainless steel, Inconel, and graphite. The test bed provided structural support and elevation during the cutting. The support also allowed for the removal of the expended vessel surrogate section and installation of a new section. The surrogate section of each vessel consisted of a cylinder that was approximately 48 inches in width and 90 inches in height (diameter). The support structure was inter-changeable with each surrogate section. 
Water collection containment was constructed with a portable filtration system for recirculation and conservation of contaminated water (simulated). A BCCI-designed cooling system was also utilized to provide the proper cooling for water circulation. A proprietary cooling system was also designed and fabricated by BCCI for the liquid nitrogen cooling application.

A radiological containment was constructed to contain airborne contaminants, water from cutting, and to simulate radiological conditions and controls. HEPA filtered ventilation was also provided by using a portable unit capable of 2,000 cubic feet per minute.

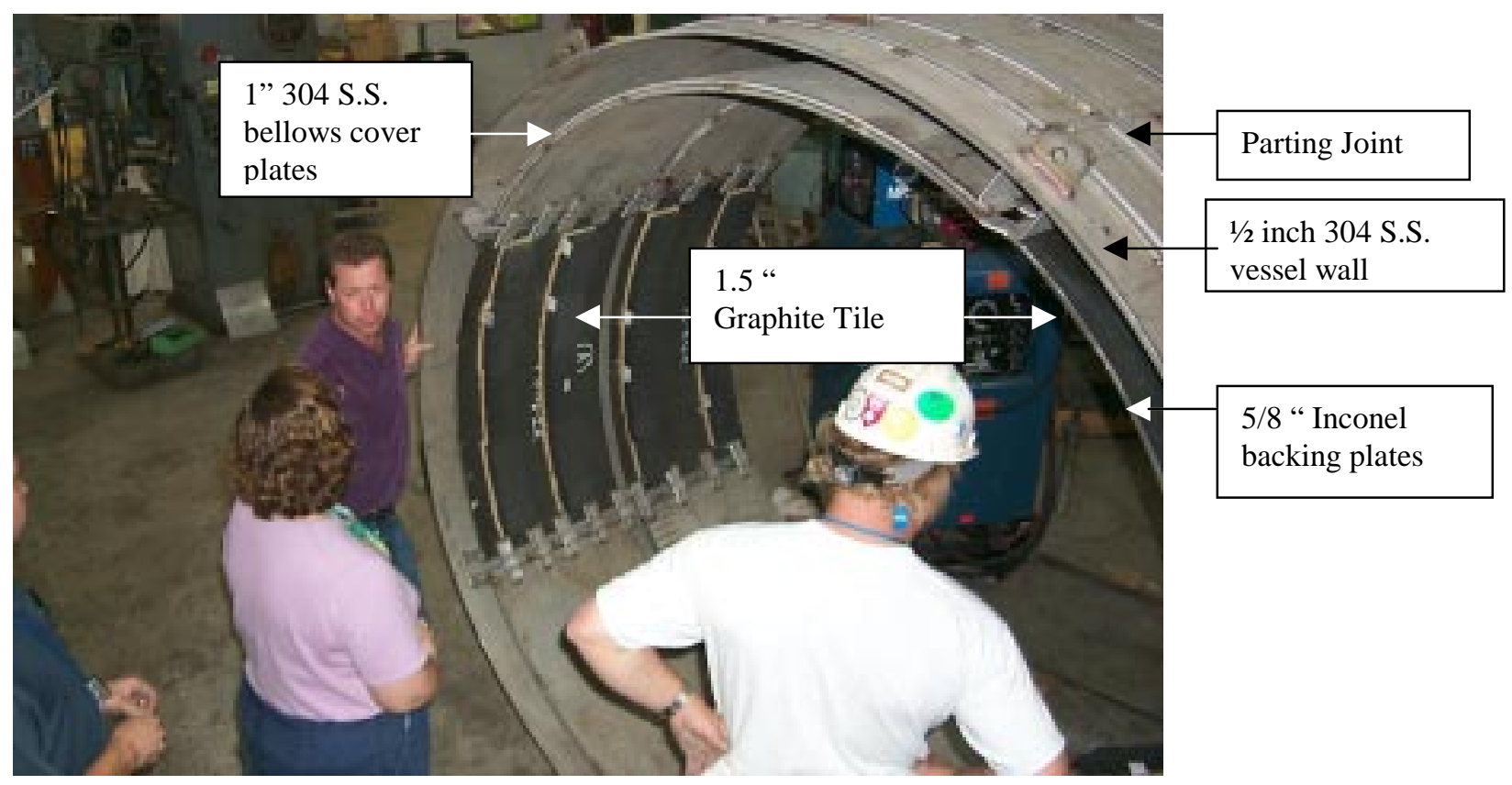

Figure 2 Vacuum vessel surrogate prior to filling

\section{OPERATION AND SYSTEM SET-UP:}

A diamond wire system provided by Bluegrass Concrete Cutting, Inc. was used for the demonstration. The diamond wire system, Figure 3, consists of a diamond matrix wire made to length for each individual cut which is driven by an electro-hydraulic drive system and supported by guide pulleys and support piping. The diamond-embedded wire consists of wire rope, springs and synthetic diamonds bonded to the outside of a steel bead. The wire is strung through the inside of the beads and springs. Adjacent to every third bead, a ring is compressed around the wire to isolate the cutting beads, in groups.

To perform a cutting operation with the diamond wire rope, it may be necessary to drill a small hole at each end of the proposed cut. The wire is either passed through the two holes or wrapped around the object to be cut and then coupled together to envelope the cut area. In the case of TFTR, the wire was wrapped around the vacuum vessel surrogate along an actual parting joint. The wire is then guided back to a drive wheel and around idler wheels that 
guide the wire. The wheel rotates and pulls the wire through the cut area. Water is typically used to cool the wire and to wash away the slurry created by the cutting operation. Wire tension is maintained via a hydraulic "stroke" cylinder that pulls the main drive wheel along its sliding carriage assembly. The main drive assembly is a simple flywheel that is either hydraulically or electrically driven.

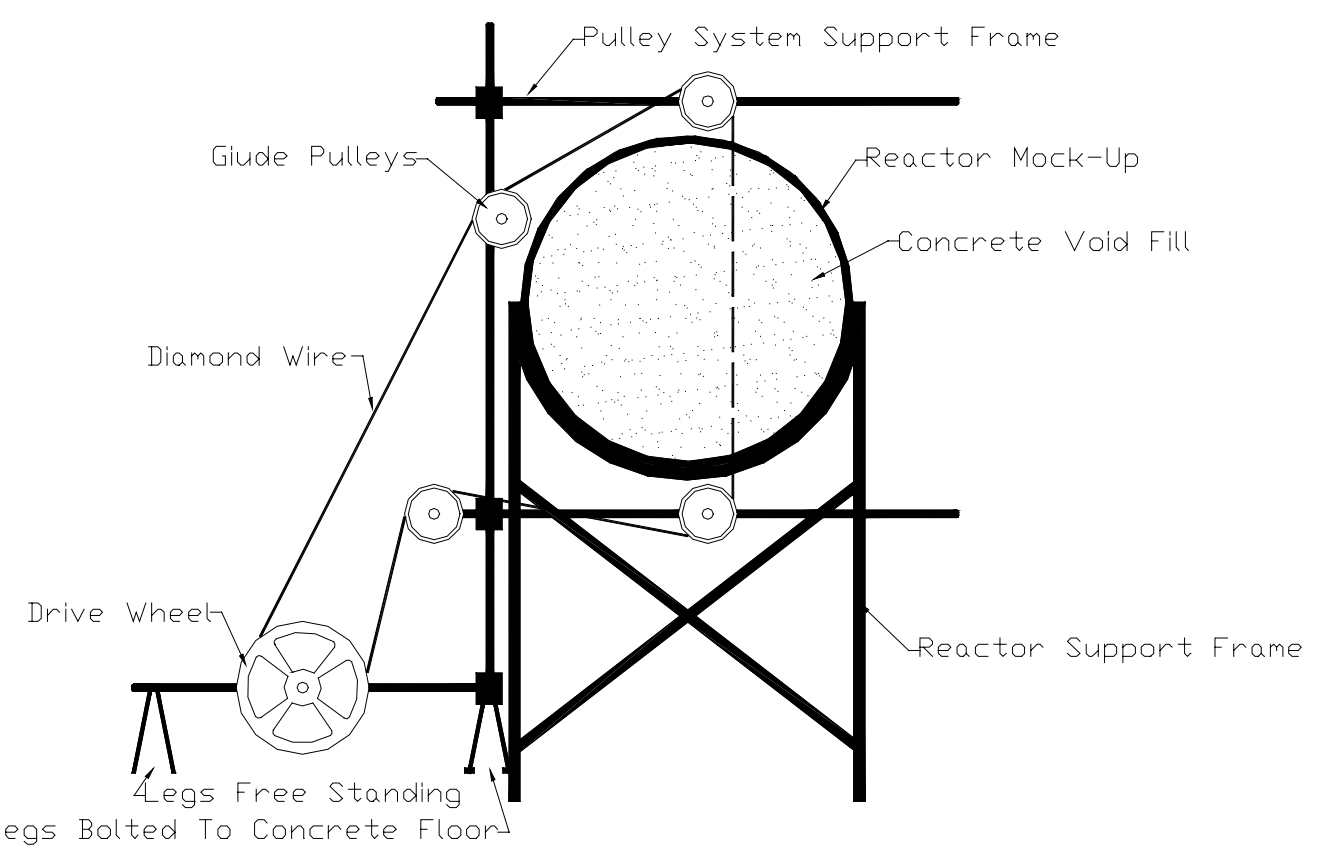

Figure 3 - Water cooling set-up

Maintenance - Required maintenance of the system is minimal. The hydraulic system is self-contained and requires checking of fluid level and inspection of hoses prior to use. The drive wheel may require replacement of a rubber belt that is in contact with the diamond wire. The guide pulleys may require replacement due to bushing wear, which causes the pulley to wobble and effect wire fluctuations and movement. These pulleys are easily unbolted and replaced upon observation of excessive wire movement.

Wire repair/replacement - A ferrule (coupling) is used to join the wire after it is wrapped around the object. A hand operated crimping tool is used to crimp each end of the ferrule onto the wire. In the event of a coupling failure (during cutting) entry into the area is necessary to cut the wire and reconfigure the spring arrangement. A new ferrule is then reinstalled.

Replacement of a diamond wire is accomplished by cutting the wire, attaching a new wire to the old wire with a ferrule, pulling the new wire into the groove using the old wire, and then cutting the old wire and crimping both ends of the new wire. 


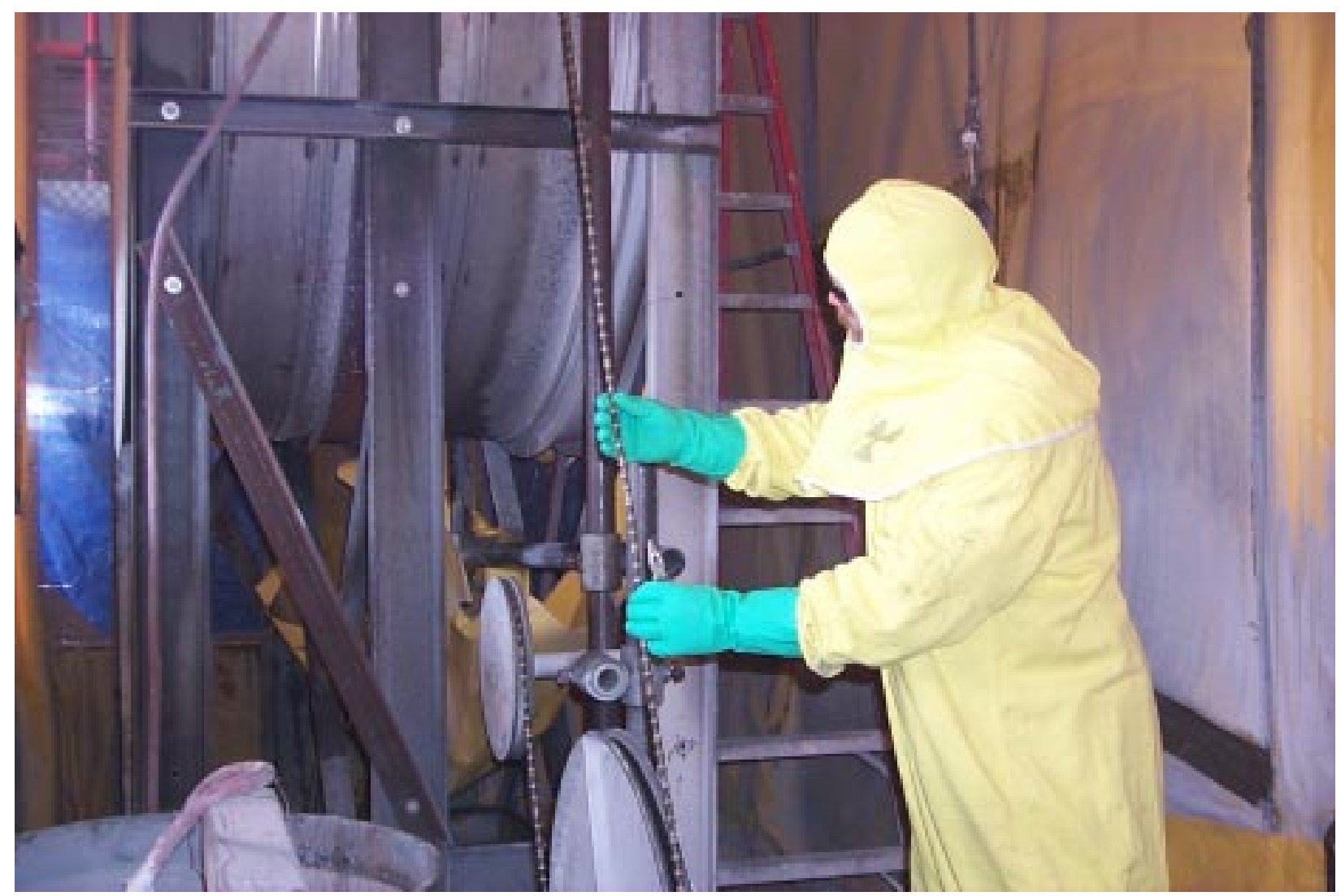

Figure 4 - Diamond Wire Rope and Pulleys

\section{VOID FILLING:}

Three void space fillers were selected for demonstration: Rheocell-15 (foamed, low-density concrete), mortar and Perma-Fill foam (aqueous based). Each was expected to maintain the structural integrity of the vessel during cutting, clean the diamond bits as they cut through the vessel, limit the dispersal of contaminants, and provide shielding during cutting operations. First surrogate was filled with a mortar and sand mixture, which had a density of approximately $120 \mathrm{lbs} / \mathrm{ft}^{3}$ and strength of $1200 \mathrm{psi}$. The second was filled with Rheocell-15, a foamed concrete product, which does not contain sand, with a density of $\sim 35 \mathrm{lbs} / \mathrm{ft}^{3}$ and strength of 128 psi. The third was filled with a rigid foam, Perma-Fill, which has a density of $\sim 1 \mathrm{lb} / \mathrm{ft}^{3}$.

The concrete void fillers were pumped into their respective surrogates using a piston-type concrete pump with a four-inch delivery hose. The Perma-Fill was pumped by the vendor directly from a truck-mounted system through a delivery manifold control system and tubing directly into the surrogate.

The optimum void fill was determined to be the low density cellular concrete, Rheocell-15 (see Table 1, below). This decision was based on the ability of the void fill to support and clean the diamond wire during cutting as well as the fact that the lesser weight represents a 
significant cost savings over the harder mortar void fill. Cutting on the surrogate filled with Perma-Fill foam was unsuccessful. The foam did not have adequate strength to provide resistive force to the wire, which caused the wire beads and springs to catch on the sharp cutting edges as the wire penetrated the vacuum vessel wall (top and bottom) causing damage to the wire in several places.

\section{COOLANTS:}

Water-cooling was the primary cooling media selected for initial cutting and evaluation of the various void filler media. Tap water was directed to the wire entry point, at the top of the surrogate, with a flow rate of approximately 1 gallon-per-minute. The water becomes entrained in the wire and kerf. As the wire exits the surrogate, the water then falls. During the demonstration a water collection system was developed to contain and collect the water. Reinforced PVC sheeting was suspended under the surrogate below the wire and guide pulleys. The majority of water was contained in the containment, which then drained to a rectangular plastic pan. The water collected in the pan was then periodically pumped to a series of three 55-gallon drums. Collected water was pumped to the first drum where sediments would settle to the bottom. As the water rose to a pre-set height, a sump pump pumped the water into the second drum. The process continued in the same manner into the third drum, which in turn provides constant metered flow to the cut location. This system provided for a quasi "closed system" water flow in order to conserve water and consequently reduce the amount of radioactive liquid generation. The system does not entirely contain the water. A small amount of water remains entrained with the wire and it misted in several directions according to the pulley configurations. The containment was maintained at negative pressure with a 2000 cubic feet per minute $(\mathrm{cfm})$ HEPA filtered ventilation system to collect particulate, and provide air change, and to simulate the evacuation of tritium containment.

Liquid nitrogen cooling was also demonstrated. The liquid nitrogen was delivered through insulated piping from a tank truck to and through the containment wall. Insulated tubing then delivered the liquid nitrogen to the cut location. This cooling method was successful. A technical comparison of the fillers and cooling agents is provide below. 
Table 1. Comparison of void fillers with respective cooling agents

Varied Void Fills and Coolants

\begin{tabular}{|c|c|c|c|c|c|}
\hline & $\begin{array}{l}\text { Rheocell-15 } \\
\text { (low density } \\
\text { concrete) - } \\
\text { Water }\end{array}$ & $\begin{array}{l}\text { Mortar - } \\
\text { Water }\end{array}$ & $\begin{array}{l}\text { Perma-Fill } \\
\text { (foam) - } \\
\text { Water }\end{array}$ & $\begin{array}{l}\text { Rheocell-15 } \\
\text { (low density } \\
\text { concrete) - } \\
\text { Air }\end{array}$ & $\begin{array}{l}\text { Rheocell-15 } \\
\text { (low density } \\
\text { concrete) - } \\
\text { Liquid } \\
\text { Nitrogen }\end{array}$ \\
\hline Cutting rate & $\begin{array}{l}0.19 \mathrm{~m}^{2} / \mathrm{h} \\
\left(2.06 \mathrm{ft}^{2} / \mathrm{h}\right)\end{array}$ & $\begin{array}{l}0.14 \mathrm{~m}^{2} / \mathrm{h} \\
\left(1.55 \mathrm{ft}^{2} / \mathrm{h}\right)\end{array}$ & NA & NA & $\begin{array}{l}0.19 \mathrm{~m}^{2} / \mathrm{h} \\
\left(2.08 \mathrm{ft}^{2} / \mathrm{h}\right)\end{array}$ \\
\hline Production rate & $\begin{array}{l}0.10 \mathrm{~m}^{2} / \mathrm{h} \\
\left(1.10 \mathrm{ft}^{2} / \mathrm{h}\right)\end{array}$ & $\begin{array}{l}0.09 \mathrm{~m}^{2} / \mathrm{h} \\
\left(1.01 \mathrm{ft}^{2} / \mathrm{h}\right)\end{array}$ & NA & NA & $\begin{array}{l}0.09 \mathrm{~m}^{2} / \mathrm{h} \\
\left(0.94 \mathrm{ft}^{2} / \mathrm{h}\right)\end{array}$ \\
\hline Area cut & $\begin{array}{l}0.82 \mathrm{~m}^{2} \\
\left(8.81 \mathrm{ft}^{2}\right)\end{array}$ & $\begin{array}{l}0.60 \mathrm{~m}^{2} \\
\left(6.49 \mathrm{ft}^{2}\right)\end{array}$ & NA & NA & $\begin{array}{l}1.24 \mathrm{~m}^{2} \\
\left(13.3 \mathrm{ft}^{2}\right)\end{array}$ \\
\hline Coolant usage $^{1}$ & $\begin{array}{l}251 \mathrm{~L} / \mathrm{m}^{2} \\
\left(6.16 \mathrm{gal} / \mathrm{ft}^{2}\right)\end{array}$ & $\begin{array}{l}419 \mathrm{~L} / \mathrm{m}^{2} \\
\left(10.3 \mathrm{gal} / \mathrm{ft}^{2}\right)\end{array}$ & $\begin{array}{l}\text { Not } \\
\text { measured }\end{array}$ & NA & $\begin{array}{l}375 \mathrm{~L} / \mathrm{m}^{2} \\
\left(9.19 \mathrm{gal} / \mathrm{ft}^{2}\right)\end{array}$ \\
\hline $\begin{array}{l}\text { Water loss } \\
\text { during cutting }\end{array}$ & $\begin{array}{l}105 \mathrm{~L} / \mathrm{m}^{2} \\
\left(2.59 \mathrm{gal} / \mathrm{ft}^{2}\right)\end{array}$ & $\begin{array}{l}157 \mathrm{~L} / \mathrm{m}^{2} \\
\left(3.85 \mathrm{gal} / \mathrm{ft}^{2}\right)\end{array}$ & $\begin{array}{l}\text { Not } \\
\text { measured }\end{array}$ & NA & NA \\
\hline $\begin{array}{l}\text { Wire wear rate } \\
\text { (\# wires/ft- } \\
\text { depth) }\end{array}$ & 1.20 & 1.18 & $\begin{array}{l}\text { Not } \\
\text { measured }\end{array}$ & Not measured & 1.21 \\
\hline $\begin{array}{l}\text { Operation } \\
\text { pressure }^{2}\end{array}$ & $\begin{array}{l}60,80-85 \text { bar } \\
(870-1233 \\
\text { psi) }\end{array}$ & $\begin{array}{l}70-85 \text { bar } \\
(1015-1233 \\
\text { psi) }\end{array}$ & $\begin{array}{l}70-75 \text { bar } \\
(1015-1088 \\
\text { psi) }\end{array}$ & $\begin{array}{l}70-75 \text { bar } \\
(1015-1088 \\
\text { psi) }\end{array}$ & $\begin{array}{l}70-75 \text { bar } \\
(1015-1088 \\
\text { psi) }\end{array}$ \\
\hline Successful & Yes & Yes & No & No & Yes \\
\hline
\end{tabular}

1 This water was recycled throughout the cutting process. The majority of the water (minus the amount lost during cutting) would need to be treated at the end of a cut or could be recycled for use on a second cut.

2 Operating pressure is the pressure applied to the wire in order to force it into the work piece.

\section{RESULTS.}

Diamond wire cutting is a mature technology for concrete cutting applications. As a result of this demonstration, the technology has also proven to be applicable to size reduction of large metal vessels such as, reactors, heat exchangers, and tanks when combined with some form of concrete matrix. This technology has now demonstrated the ability to cut large metal structures containing softer metals, such as stainless steel, and one of the hardest metals, Inconel, in conjunction with a concrete-matrix. In addition, diamond wire cutting technology 
is particularly advantageous when compared to the significant health and safety concerns associated with the baseline technology. Lighter weight concrete, such as Rheocell-15 increased the capability of this technology while providing for radionuclide stabilization, strength, and shielding. This technology is superior to plasma arc cutting for large metal vessels and heat exchangers, and is particularly advantageous to those objects that are too large to ship or possess significant radiological hazards.

The Diamond Wire Cutting technology was performed successfully using liquid nitrogen or water-cooling. The DWC provided significant improvements in worker safety and cutting performance as compared to the baseline. A performance comparison between the two technologies is listed in Table 2.

Table 2: Performance comparison between the DWC and the baseline technology

\begin{tabular}{|c|c|c|}
\hline Performance Factor & Baseline Technology & Diamond Wire Cutting \\
\hline $\begin{array}{l}\text { Number of } \\
\text { personnel required } \\
\text { in vacuum vessel }\end{array}$ & \begin{tabular}{l}
\multicolumn{1}{c}{2 to 3 people } \\
(2 workers to remove tiles, remove \\
other internal components and \\
operate plasma system)
\end{tabular} & 0 person \\
\hline $\begin{array}{l}\text { Number of } \\
\text { personnel required } \\
\text { outside } \\
\text { contamination area }\end{array}$ & $\begin{array}{l}\qquad 8-9 \text { people } \\
\text { (4 support people for air system ops, } \\
\text { IH, and safety oversight, } 2-3 \mathrm{RCT} \text { to } \\
\text { monitor radiation readings and } \\
\text { survey equipment out of } \\
\text { contamination area) }\end{array}$ & \begin{tabular}{l}
\multicolumn{1}{c}{2 people } \\
(1 worker to operate DWC, 1 RCT to \\
survey equipment out of \\
contamination area)
\end{tabular} \\
\hline $\begin{array}{l}\text { Time to assemble } \\
\text { and setup equip. }\end{array}$ & $72 \mathrm{hrs}$ & $46 \mathrm{hrs}$ \\
\hline $\begin{array}{l}\text { Time to segment } \\
\text { vacuum vessel (avg.) }\end{array}$ & $35 \mathrm{hrs}$ & $24 \mathrm{hrs}$ \\
\hline $\begin{array}{l}\text { Expected total whole } \\
\text { body exposure }\end{array}$ & $1380 \mathrm{mRem}$ & $20 \mathrm{mRem}$ \\
\hline $\begin{array}{l}\text { Expected release of } \\
\text { tritium }\end{array}$ & 23 Curies & 8 curies \\
\hline PPE requirements & Air supplied bubble suits & $\begin{array}{c}\text { Coveralls, hood, etc. (respirators } \\
\text { possible) }\end{array}$ \\
\hline Superior capability & $\begin{array}{l}\text { Plasma cutting is preferable for } \\
\text { single layer cutting of metal plate } \\
\text { and structural steel provided that } \\
\text { proper health and safety controls } \\
\text { can be implemented. }\end{array}$ & $\begin{array}{l}\text { DWC is operated remotely and } \\
\text { provides significant reduction in } \\
\text { personnel exposure and } \\
\text { radionuclide emissions. } \\
\text { DWC, when combined with } \\
\text { lightweight concrete void fillers, is } \\
\text { the only technology capable of } \\
\text { cutting complex structures with } \\
\text { multiple layers of steel, including } \\
\text { hardened steel such as inconel? }\end{array}$ \\
\hline
\end{tabular}




\section{COST:}

The cost to use the innovative technology, diamond wire with water coolant, are approximately $87 \%$ of the cost of using the liquid nitrogen coolant with the innovative technology and approximately 37\% of the cost of using the baseline technology for this demonstration. The savings from baseline result from the fact that when using the innovative technology, no internal components of the vessel vacuum has to be removed prior to cutting, and the vacuum vessel will be void filled prior to cutting encapsulating the tritium in concrete. This reduces the number of containments required for the cut and the number of personnel at the work site.

Cutting of the TFTR mockup would be performed in different ways for the two technologies. The innovative technology, diamond wire saw, would cut through the reactor and void fill for a total cut area of $4.15 \mathrm{~m}^{2}\left(44.7 \mathrm{ft}^{2}\right)$. The baseline technology, however, would make three cuts around the circumference of the reactor (two inside and one outside) for a total linear cut length of $21.8 \mathrm{~m}(71.5 \mathrm{ft})$. Two parallel cuts, approximately 6 inches apart, inside the vacuum vessel are necessary to remove the internal plates to provide access to the vessel wall for further cutting. Cutting rates for the two technologies are therefore expressed in different units. The diamond wire saw has a cutting rate of $0.32 \mathrm{~m}^{2} / \mathrm{h}\left(3.42 \mathrm{ft}^{2} / \mathrm{h}\right)$. This cutting rate is the same for both water-coolant and liquid nitrogen coolant. The plasma torch's cutting rate is $12 \mathrm{~m} / \mathrm{h}(39.3 \mathrm{ft} / \mathrm{h})$.

The major difference in the costs for the innovative and baseline technologies is the necessity for personnel to enter the reactor vessel during the baseline technology. This is necessary to complete the following activities:

- remove graphite tiles prior to cutting since the plasma torch will not cut through graphite.

- remove the tile backing plates, protective plates, etc. in order to cut the outer vessel wall.

- setup the remotely operated plasma torch equipment.

- reposition on the outside of the reactor after the internal cutting is completed.

- remove all debris and cut media at the end.

These activities require additional containment and ventilation, a higher level of PPE protection (Level A), and additional personnel due to increased risk of tritium contamination.

Tables 3 lists the unit costs to perform one complete cut through the vacuum vessel for the innovative and baseline technologies. Refer to the Construction section, above, for dimensions and material construction. The unit costs are based on the detailed costs contained in the project Innovative Technology Summary Report, which can be found at: ftp://ftp.em.doe.gov/pub/incoming/ITSRs/DDFA/. 
WM00 Conference, February 27- March 2, 2000

Table 3. Unit cost for each technology to perform one complete cut through the vacuum vessel

\begin{tabular}{|l|c|c|c|}
\hline \multicolumn{1}{|c|}{ Technology } & Total Cost & $\begin{array}{c}\text { Cutting } \\
\text { Rate }\end{array}$ & $\begin{array}{c}\text { Cutting } \\
\text { Time }\end{array}$ \\
\hline $\begin{array}{l}\text { Diamond wire saw - water } \\
\text { coolant }\end{array}$ & $\$ 45,531$ & $\begin{array}{c}0.32 \mathrm{~m}^{2} / \mathrm{h} \\
\left(3.42 \mathrm{ft}^{2} / \mathrm{h}\right)\end{array}$ & $13 \mathrm{~h}$ \\
\hline $\begin{array}{l}\text { Diamond wire saw - LN } \\
\text { coolant }\end{array}$ & $\$ 52,046$ & $\begin{array}{c}0.32 \mathrm{~m}^{2} / \mathrm{h} \\
\left(3.42 \mathrm{ft}^{2} / \mathrm{h}\right)\end{array}$ & $13 \mathrm{~h}$ \\
\hline Plasma torch & $\$ 123,391$ & $\begin{array}{c}200 \\
\mathrm{~mm} / \mathrm{min} \\
(39.3 \mathrm{ft} / \mathrm{h})\end{array}$ & $1.8 \mathrm{~h}$ \\
\hline
\end{tabular}

Tables 4 and 5 show a relative percentage for each activity of the demonstration. This percentage represents each activity's cost relative to the total cost of the job. Additionally, the site-specific conditions that can affect the cost of the activity are identified on the right side of the table.

Table 4. Breakdown of innovative technology total cost

\begin{tabular}{|c|c|c|c|}
\hline Activities & $\begin{array}{l}\text { Percent of } \\
\text { Total Cost } \\
\text { (Water } \\
\text { Coolant) }\end{array}$ & $\begin{array}{l}\text { Percent of } \\
\text { Total Cost } \\
\text { (LN } \\
\text { Coolant) }\end{array}$ & Site Specific Conditions \\
\hline Cut Reactor Mockup & 44.5 & 53.4 & $\begin{array}{l}\text { Cut } 44.7 \mathrm{ft}^{2} \text { of stainless steel and } \\
\text { inconel (includes liquid nitrogen } \\
\text { cost of } \$ 0.77 / \mathrm{L} \text { ) }\end{array}$ \\
\hline Erect Enclosure & 10.2 & 8.9 & Size $24.5 \mathrm{ft} \mathrm{L}$ x $8.25 \mathrm{ft} \mathrm{W}$ x $16 \mathrm{ft} \mathrm{H}$ \\
\hline $\begin{array}{l}\text { Additional Productivity } \\
\text { Activities }\end{array}$ & 6.8 & 7.8 & $\begin{array}{l}8.6 \mathrm{~h} \text { (water), } 12.2 \text { (LN) non-cutting } \\
\text { activities }\end{array}$ \\
\hline $\begin{array}{l}\text { Transport To and From } \\
\text { Site }\end{array}$ & 6.6 & 5.8 & Vendor provided cost \\
\hline Disassemble Equipment & 5.7 & 5.0 & $\begin{array}{l}8 \mathrm{~h} \text { decontamination and survey of } \\
\text { equipment }\end{array}$ \\
\hline Void Fill Reactor & 5.4 & 4.8 & $6.5 \mathrm{yd}^{3}$ Rheocell-15 \\
\hline Solid Waste Disposal & 4.1 & 2.0 & $34 \mathrm{ft}^{3}$ (water), $19 \mathrm{ft}^{3}(\mathrm{LN})$ \\
\hline Vendor Matriculation & 4.0 & 4.4 & $\begin{array}{l}\text { GET, Rad Worker, Cryogenic } \\
\text { training (for LN only) }\end{array}$ \\
\hline $\begin{array}{l}\text { Treatment of Water and } \\
\text { Slurry }\end{array}$ & 4.0 & 0 & 65 gallon water to be solidified \\
\hline Remove Enclosure & 3.4 & 3.2 & $12 \mathrm{~h}$ to remove \\
\hline Setup Equipment & 2.5 & 2.4 & $\begin{array}{l}\text { Includes water containment system } \\
\text { or LN lines }\end{array}$ \\
\hline $\begin{array}{l}\text { Replace/Splice Diamond } \\
\text { Wire }\end{array}$ & 2.4 & 2.1 & $\begin{array}{l}9 \text { coupling changes and } 6 \text { wire } \\
\text { changes }\end{array}$ \\
\hline Load Equipment & 0.3 & 0.2 & $0.5 \mathrm{~h}$ to load equipment \\
\hline $\begin{array}{l}\text { Unload/Move Equipment } \\
\text { to Work Area }\end{array}$ & 0.1 & 0.1 & $0.25 \mathrm{~h}$ to unload equipment \\
\hline
\end{tabular}


WM00 Conference, February 27- March 2, 2000

Table 5. Breakdown of baseline technology total cost

\begin{tabular}{|c|c|c|}
\hline Activities & $\begin{array}{l}\text { Percent of } \\
\text { Total Cost }\end{array}$ & Site Specific Conditions \\
\hline Setup Equipment & 43.3 & $\begin{array}{l}\text { Includes price for custom-made remotely } \\
\text { operated plasma torch. }\end{array}$ \\
\hline Erect Enclosure for Vessel Entry & 10.2 & $1000 \mathrm{ft}^{3}$ PVC enclosure. \\
\hline Remove Bellows Cover Plates & 9.8 & $\begin{array}{l}16 \mathrm{~h} \text { to unbolt stacked bars on outside of } \\
\text { VV }\end{array}$ \\
\hline Floor Installation in VV & 8.3 & $8 \mathrm{~h}$ install, includes lighting \\
\hline PPPL Worker Training & 4.7 & $\begin{array}{l}\text { Mockup training and air-fed PPE suit } \\
\text { training for } 19 \text { site personnel }\end{array}$ \\
\hline Erect Enclosure Outside VV & 3.9 & Size $24.5 \mathrm{ft} \mathrm{L}$ × $8.25 \mathrm{ft} \mathrm{W}$ x $16 \mathrm{ft} \mathrm{H}$ \\
\hline Reposition Equipment & 3.5 & $\begin{array}{l}6 \mathrm{~h} \text { to reposition from inside to outside } \\
\mathrm{VV}\end{array}$ \\
\hline Remove Materials from Internal & 3.1 & $8 \mathrm{~h}$ for $7 \mathrm{D} \& \mathrm{D}$ workers \\
\hline Solid Waste Disposal & 2.6 & $59 \mathrm{ft}^{3}$ includes plasma torch \\
\hline Remove VV Entry Enclosure & 2.5 & $16 \mathrm{~h}$ to remove \\
\hline Remove Graphite Tiles & 2.4 & $4 \mathrm{~h}$ to remove prior to cutting \\
\hline Void Fill Reactor & 2.0 & $6.5 \mathrm{ft}^{3}$ after cutting \\
\hline $\begin{array}{l}\text { Decontaminate, Package } \\
\text { Equipment }\end{array}$ & 1.8 & $\begin{array}{l}16 \mathrm{~h} \text { to decontaminate and survey } \\
\text { equipment }\end{array}$ \\
\hline Remove Remaining Enclosure & 1.3 & $12 \mathrm{~h}$ to remove \\
\hline Cutting of Circumference & 0.4 & $\begin{array}{l}7.87 " / \mathrm{min} \text { cutting rate }(200 \mathrm{~mm} / \mathrm{min} .) \text {, } \\
23.8 \mathrm{ft} \text { cut length }\end{array}$ \\
\hline Cutting of Internal Components & 0.2 & 2 parallel cuts, $47.6 \mathrm{ft}$ length \\
\hline
\end{tabular}

For this demonstration, the innovative technology saves approximately $\$ 70,000$ over the baseline for a similar job size. At this rate of savings, the purchase price for the diamond wire saw would result in a total equipment cost of $\$ 66,700$, which would be recovered in the first job using the innovative technology.

- $\quad$ saw and equipment $(\$ 43,000)$ Re-use

- $240 \mathrm{ft}$ of plated diamond wire $(\$ 18,720)$ Consumable

- liquid nitrogen coolant equipment $(\$ 5,000)$ Re-use

\section{LESSONS LEARNED}

Diamond wire cutting is a mature technology for concrete cutting applications. As a result of this demonstration, the technology has also proven to be applicable to size reduction of large metal vessels such as, reactors, heat exchangers, and tanks when combined with some form of concrete matrix. The technology is particularly advantageous when there are significant health and safety concerns with the baseline technology. Utilization of a skilled and experienced operator/vendor is critical to the cutting success and performance. Selection of a concrete filler that meets the cutting, stabilization, and shipping constraints is also critical to the success of the project. 
Strong consideration must be given to the selection of water or liquid nitrogen as the cooling media. This decision must be based upon particular radionuclide hazards and their application to feasible engineering controls for each media. Liquid waste generation and the subsequent solidification and treatment can be costly and difficult. In contrast, the airborne dry particulate generated when using LN cooling is a concern along with oxygen deficiency. Removal of the graphite tiles at the cutting locations is receiving strong consideration in future planning to reduce emissions during cutting.

The TFTR segmentations were limited to a $10-\mathrm{mm}$ wire diameter due to the width of the parting joint. The use of a larger diameter wire would result in cutting through the shoulders of the parting joint which increases the amount of material (stainless steel) to be cut before cutting of the actual vessel wall. If the structure (to be cut) allows the use of a larger diameter wire, greater tension can be placed on the wire, which can increase cutting rate. Utilization of a skilled and experienced operator/vendor is critical to the cutting success and performance. Selection of a concrete filler that meets the cutting, stabilization and shipping constraints is also critical to the success of the project

\section{SUMMARY;}

Based upon the demonstration at PPPL on the TFTR surrogate, the diamond wire cutting technology is superior to the baseline technology for both cost and safety considerations. The combination of void filling with this cutting technology will significantly reduce personnel radiation exposure through shielding, remote operation (normal application of this technology), and radionuclide stabilization.

Both low-density concrete and mortar proved to be acceptable void fillers and provide numerous benefits, both for health and safety, and technical performance.

Liquid nitrogen and water proved to be effective cooling media. The choice of either will depend upon evaluation of the radioisotopes of concern and associated hazards presented by the methods of engineering control, respiratory protection, and waste management.

\section{ACKNOWLEDGMENTS:}

We would like to acknowledge the financial and management support provided by the D\&D Focus Area team at Federal Energy Technology Center in Morgantown, West Virginia. In particular, Dr. Paul Hart, Jerry Hyde and Steve Bossart. Mr. Mark Wareing of AEA Technologies, Inc. also provided engineering and technical assistance during the demonstration which proved to be critical to the success.

We also recognize the contributions and accomplishments of the following PPPL personnel who assisted with the successful development and fabrication of this demonstation. Fabrication and Assembly - Steve Kemp, Robert Delaney, Joseph Bartzak, Robert Horner, Paul Kivler and George Proesser. Engineering - Larry Dudek, Robert Parsells, Environmental Safety and Health - William Slavin and Jerry Levine 
WM00 Conference, February 27- March 2, 2000

\section{References:}

1. Bach, Fr.-W, Steiner, H, and Pilot, G., Year. Analysis of Results obtained with different cutting techniques and associated filtration systems for the dismantling of radioactive metallic components. Journal volume information: pgs. 680-700.

2. Litka, Tom J., Advances Consulting Group, Inc. for PPPL, "TFTR Vacuum Vessel Segmentation

Approaches Study, December 1994". 